Esboço de Letras

\section{Caminhos da Cultura: perspectiva comparada entre David Hume} e Norbert Elias

Paths of Culture: comparative perspective between David Hume and Norbert Elias André Vicente Pintor ${ }^{* *}$

Recebido em: 20.03 .2017 Aprovado em: 20.09.2017.

Graduando em Ciências Sociais pela Universidade de Brasília. Email: andre.v.pintor@gmail.com
Resumo: este artigo buscou identificar as continuidades e descontinuidades entre as obras de David Hume e Norbert Elias com referência ao tema da vida social humana. A principal continuidade que observamos é a requisição da história como fonte explicativa dos costumes compartilhados socialmente - característica essa que relacionamos ao conceito de cultura. Ademais, observamos um progressivo afastamento do princípio da racionalidade como organizador universal das relações humanas. Consequência disto é uma diferença patente na obra dos dois autores: a obra de Elias é requisitada a trabalhar em uma perspectiva interdisciplinar para dar conta de compreender uma racionalidade que não é absoluta, mas relacional - e que permeia processos sociais e individuais que não são apenas mentais.

Palavras-chave: Cultura; David Hume; Norbert Elias; subjetivação; processos de sociogênese e psicogênese.
Abstract: this study has highlighted the differences and similarities of David Hume and Norbert Elias' work as to the subject of humans' life in society. The theories here considered are very much alike in their treatment of history as a comprehensive source for the understanding of socially shared manners - what we call "culture". In addition, they could be arranged as to illustrate a progressive depart of the social sciences from the principle of rationality as an a priori of human interactions. As an aftermath of this departure, Elias' works has to deal in a much more interdisciplinary way than Hume's, seeking to comprehend a rationality that is relative, and not absolute - and which impregnates social and individual processes that are not only mental.

Keywords: Culture; David Hume; Norbert Elias; subjectivation sociogenesis and psychogenesis processes. 


\section{André Vicente Pintor}

\section{Introdução}

Neste artigo, buscaremos identificar continuidades e descontinuidades entre as concepções de ser humano (em sua relação com o mundo e com seu ambiente social) nas obras de David Hume e Norbert Elias. Para tanto, analisaremos O Processo Civilizador, informados por A Sociedade dos Indivíduos, e nos utilizaremos da explicação do Tratado da Natureza Humana apresentada por Gilles Deleuze em Empirismo e Subjetividade. As duas concepções que identificaremos aqui serão referidas pelo termo "cultura", o que exprime nosso empenho em mostrar suas continuidades. Por outro lado, comparando-as, também atravessaremos algumas criações teóricas que foram fundamentais para seu distanciamento, intentando compreender o papel de cada uma nesta diferenciação.

A justificativa que nos permite abordar ambas concepções segundo a ideia de "cultura" é dada pelo trabalho de Franz Boas em $A$ Formação da Antropologia Americana - principalmente pela contribuição de Rudolf Virchow que o autor identifica como indispensável à antropologia contemporânea. Neste livro, num artigo sobre a história da antropologia, Boas trata de uma "teoria histórica" (BOAS, 2004, p. 50-51) em que a cultura é tratada como uma tradição (linguística, artística, mitológica, comportamental) transmitida e reformulada pelas diferentes gerações de um povo. A concepção fundamental desta teoria teria advindo dos trabalhos anatômicos de Virchow: nela, é imprescindível a ideia de que cada geração depende diretamente da geração anterior, podendo mudar de forma de acordo com as influências a que estão sujeitas (ibid., p. 59).
A possibilidade que a partir daí se insere na antropologia é a de uma crítica ao evolucionismo e à possibilidade de um rumo histórico humano determinado por forças supra-humanas. Se torna crucial à cultura, portanto, que se considere que ela é uma forma de portar-se no mundo determinada por influências históricas concretas, estando também sempre sujeita, por sua vez, a futuras mudanças. Esta característica fundamental, como veremos, se encontra presente tanto no pensamento de Hume como no de Elias.

A partir dessas ideias de "cultura", o movimento que traçaremos aqui é o de um progressivo afastamento da teoria social com relação à ideia de civilização, atravessando os limites de sua possibilidade de sustentação. A civilização é entendida por nós como o conceito representante do evolucionismo social que Boas combate: seja por determinações supra-humanas, seja por uma especificidade histórica que eleva uma cultura a um patamar superior a todas as outras, sua premissa básica é a de que existe um ponto final de desenvolvimento humano no qual se pode chegar. Demonstraremos como Hume dá o passo inicial no afastamento desta premissa e como, finalmente, ela se torna insustentável em Elias.

\section{A Cultura em Hume}

Vale ressaltar que o termo "cultura" não chega a aparecer no Tratado da Natureza Humana - em seu lugar, Hume fala de uma "consciência moral" ou de "regras gerais" da moralidade. Todavia, no texto do qual nos utilizamos aqui como forma de mediação com esta obra, Deleuze se utiliza repetidas vezes do termo, imprimindo-lhe um 
1 “[...] o sentido de justiça e injustiça não deriva da natureza, surgindo antes artificialmente, embora necessariamente, da educação e das convenções humanas." (HUME, 2009, p. 524).

2 "A natureza certamente é capaz de produzir tudo aquilo que pode surgir do hábito. Ou antes: o hábito não é senão um dos princípios da natureza, e extrai toda a sua força dessa origem." (HUME, 2009, p. 212).

\section{André Vicente Pintor}

conceito posterior à sua escrita. Nos sentimos justificados a empregar o termo cultura com referência às ideias de Hume, portanto, não apenas pelo que já argumentamos, em nossa introdução, sobre a noção de historicidade, mas também pelo trabalho de Deleuze. Dito isto, passemos à análise da cultura em Hume a partir de Empirismo e Subjetividade.

Para Deleuze, é importante entender que o projeto de Hume é o do estabelecimento de uma verdadeira ciência do homem. Neste sentido - e sob o ponto de vista empirista de Hume -, seu problema fundamental é o de como o Espírito devém uma Natureza humana (DELEUZE, 2001, p. 12) - não são as características do Espírito que lhe interessam, mas as características daquilo que lhe afeta. A história se torna fundamental, então, para Hume, pois é a ciência que permite a compreensão dessas afecções; ela permite o estudo das "relações motivo-ação no máximo de circunstâncias dadas, manifesta a uniformidade das paixões do homem" ao analisar seus modos de organização política e suas instituições sociais (DELEUZE, 2001, p.11). Deleuze afirma, portanto, que antes de ser um psicólogo, e para ser um psicólogo, Hume é um moralista, um sociólogo e um historiador.

É esta abordagem histórica, que fundamenta todas as considerações de Hume acerca da moral, que nos permite afirmar que neste autor se encontra o protótipo da ideia de cultura que tomamos por base neste trabalho. Diferentemente dos autores racionalistas ou idealistas que disputavam consigo a determinação do fundamento da moralidade, Hume não acreditava que esta poderia ser fundamentada em outra coisa que não a própria sociedade ${ }^{1}$; não poderia estar destacada desta, exercendo influência externa sobre ela. Tudo o que é moral deveria estar referenciado na própria história humana.

Ao falarmos de uma história humana, estamos falando também de uma natureza humana. Deleuze se esforça para mostrar, entretanto, que sempre que Hume fala de uma natureza humana, ele está falando, ao mesmo tempo, de algo inato e histórico; uma predisposição universalmente humana à diferença e inconstância ${ }^{2}$. Esta diferença é determinada pela história, compreendida sob um ponto de vista diferencial acerca das soluções que um povo encontra para seus problemas - o que quer dizer que, para Hume, a história de um povo não pode ser apresentada como um estágio localizado num continuum de desenvolvimento em direção a uma realidade moral compartilhada por diferentes sociedades.

O que é natural no ser humano é determinar-se; é seu autoestabelecimento para além da natureza. Dizer isto é dizer que o ser humano é sujeito; torna-se sujeito. A subjetivação alcança lugar central na análise deleuziana da obra de Hume, pois é a consumação das afecções do Espírito. Não é somente naquilo que há de comum a todos que a verdadeira ciência do homem deve se pautar, mas também naquilo que há de diferente. É esta a importância da história em Hume; é este o significado do Sujeito. Mas como nos tornamos sujeitos? Como somos afetados? "O Tratado mostrará que as duas formas sob as quais o espírito é afetado são, essencialmente, o passional e o social" (DELEUZE, 2001, p.11). São estas as duas 


\section{André Vicente Pintor}

${ }^{3}$ Em Hume (2009, p. 299): "E como devemos ficar desapontados, quando descobrimos que essa conexão, laço ou energia se encontra unicamente dentro de nós mesmos, e não é mais que a determinação da mente, adquirida pelo costume, que nos leva a fazer uma transição de um objeto àquele que usualmente o acompanha. do outro!".

4 "Uma das mais importantes ideias de Hume, e que ele fará valer particularmente contra a possibilidade de toda cosmologia e de toda teologia, é que não há conhecimento intensivo, sendo tão somente possível o conhecimento extensivo, entre partes." (DELEUZE 2001, p. 144). Este excerto deixa evidente a impossibilidade de conhecimento da "coisa em si", sob um ponto de vista empirista, como um corolário do princípio do dualismo entre o dado e suas relações. Se o dado não pode ser conhecido intensivamente, é lógico que o trabalho de Hume volte-se para entender como as relações são imprimidas sobre o dado. enquanto observadores formas pelas quais o espírito se torna sujeito. Isto é, em outras palavras: as formas pelas quais se dá a subjetivação, a diferença.

Entender a subjetivação é essencial para entender o trabalho de Hume, pois é no Sujeito que se manifesta a natureza humana. Empirista, o autor trabalha com um dualismo: o dado, entendido como os poderes da Natureza, isto é, aquilo que se encontra no mundo da maneira como realmente é; e as relações no dado, que só podem ser estabelecidas por quem o observa, mas nunca estão realmente nele. O princípio fundamental é o de que as relações não podem decorrer da natureza das coisas, mas apenas de nossa natureza

Devemos dizer, portanto, que o empirismo só se define verdadeiramente em um dualismo: dualismo entre os termos e as relações; entre a causa das percepções e a causa das relações; os poderes ocultos da Natureza e os princípios da natureza humana. Denominar-se-á, portanto, nãoempirista toda teoria segundo a qual, de uma ou outra maneira, as relações decorram da natureza das coisas. (ibid., p. 123)

O espírito, que já mencionamos, é relacionado em Hume com os poderes da natureza; ele é o dado. Enquanto isso, o sujeito são as relações que se estabelecem sobre esse dado; são uma constância que se imprime nos modos como os elementos do dado serão relacionados: a natureza humana é dada, mas seu conteúdo não pode sê-lo. Ora, a verdadeira ciência do homem que Hume busca, portanto, volta-se justamente para a forma pela qual essas relações são estabelecidas: ela deve entender como podemos inventar relações onde não existe nenhuma, e o que justifica nossa crença nessas relações.
“[...] Princípios da natureza humana é que transformam o espírito em um sujeito, que constituem um sujeito no espírito" (ibid., p. 110). O que são esses princípios? "Não se trata de perguntar o que são os princípios, mas o que eles fazem. Não são seres, mas funções. Eles se definem pelos seus efeitos. Esses efeitos se reduzem ao seguinte: esses princípios constituem no dado um sujeito que inventa e crê" (DELEUZE, 2001, p. 150) ${ }^{3}$. Ao tratar de tais princípios da natureza humana, portanto, Hume não lhes atribui uma gênese, mas apenas uma ação. Isto porque sua importância está justamente nos efeitos que produzem, e não de onde vieram - como já dissemos, Hume não está interessado nos estudos do Espírito, mas de suas afecções (aliás, este é o único estudo possível, tendo em vista que o dado por si só não apresenta nenhuma relação, nenhuma possibilidade de conhecimento verdadeiro ${ }^{4}$ )

Entendidos enquanto efeitos, os princípios da natureza humana podem ser divididos em duas classes: princípios de associação e princípios da paixão. Os princípios de associação são o equivalente ao que autores de sua época chamariam de Razão. Tendo como seu resultado particular a inferência, eles são a instância do Sujeito que relaciona percepções umas às outras, decorrendo umas de outras. Suas três formas são a contiguidade, a semelhança e a causalidade (ibid., p. 113), que operam fornecendo ao Sujeito regras gerais segundo as quais ele deve estabelecer relações entre os termos do Espírito.

Os princípios de associação estabelecem entre as ideias relações naturais. Eles formam no espírito toda uma rede, como uma canalização: não é por acaso que se passa de uma ideia a outra; uma ideia 
5 Na verdade, A não tem tanta probabilidade de despertar B quanto B tem de despertar A porque os princípios de associação nunca agem no Espírito separados dos princípios da paixão que, como veremos, imprimem uma direção a essa relação. Entretanto, separando analiticamente um e outro tipo de princípios, o caráter extensivo que rege os princípios de associação teriam justamente $\mathrm{o}$ efeito de estabelecer tal reciprocidade entre A e B.

${ }^{6}$ Em Hume (2009, p. 458): "O costume tem dois efeitos originais sobre a mente: confere a ela uma facilidade para realizar uma ação ou para conceber um objeto; e, posteriormente, uma tendência ou inclinação a fazê-lo." (grifo do autor) introduz naturalmente uma outra de acordo com um princípio, sendo naturalmente acompanhada por outra. (ibid., p. 139)

É importante frisar que os princípios da associação são incapazes de atribuir um sentido às relações que estabelecem. Ao criar essa rede de ideias, não imprimem no sujeito a impressão de que uma ideia é mais importante que a outra: elas são ligadas em uma via de mão-dupla, onde A tem tanta probabilidade de despertar B quanto B tem de despertar $A^{5}$.

Se os princípios da associação relacionam as ideias recíproca e indiferenciadamente, os princípios da paixão conferem a essas relações um sentido, atribuem-lhe um "primeiro termo" a partir do qual o Sujeito fará suas inferências:

[...] essas qualidades da paixão não fixam a imaginação da mesma maneira que os modos de associação. Estes davam às ideias relações recíprocas possíveis; aquelas dão uma direção, um sentido a essas relações, atribuindo-lhes uma realidade, um movimento unívoco, um primeiro termo, portanto. (DELEUZE, 2001, p. 63)

As relações naturalmente estabelecidas pelos princípios da associação recebem agora uma tendência associativa; seguem uma determinada direção em detrimento das diversas outras que poderiam seguir. "Se os princípios de associação explicam que as ideias se associam, somente os princípios da paixão podem explicar que sobretudo uma ideia e não outra esteja associada a tal outra ideia em tal momento." (ibid., p.117) ${ }^{6}$

Vemos que a natureza humana se baseia em estabelecer relações e conferir a elas uma orientação, uma constância e predisposição a relacionar determinados termos de forma específica, deixando de lado outras relações possíveis. Tornar-se sujeito, então, é justamente adquirir esta tendência. A subjetividade é a instância propriamente humana no mundo das coisas; são as relações imprimindo-se sobre o dado de maneira particular.

Quando Deleuze afirma que o social e o passional são as formas sob as quais o espírito é afetado, e sabendo que o espírito afetado devém sujeito, constatamos que a natureza humana é moldada pelo passional e pelo social. Tanto um quanto o outro são efeitos dos princípios da paixão no espírito, repousando sua diferença na origem da requisição que se faz a ele: o passional é entendido de forma mais individual, ativando o espírito a partir da experiência única que constitui o sujeito que ele informa; o social, diferentemente, surge como uma demanda de adequação do sujeito à sociedade, isto é, a outros sujeitos. Na interação entre um e outro, reside a teoria moral de Hume.

Como falamos, os princípios da paixão dão um sentido às relações estabelecidas pelos princípios de associação, imprimindo a elas uma tendência associativa em uma determinada direção. Qual é esta direção? “[...] os princípios da paixão designam certas impressões que ele, o espírito, designa como fins de nossa atividade" (ibid., p. 140). Ao falarmos de um sujeito que é constituído, portanto, estamos falando de um espírito que é movimentado na direção de uma finalidade; subjetivar-se é adquirir fins. Esta finalidade que orienta o sujeito, por sua vez, é basicamente instruída por dois princípios: aproximar-se do prazer e afastar-se da dor. 
7 Em Hume (2009, p. 486): “[...] quando a mente busca um fim com paixão, mesmo que essa paixão não derive originalmente do fim, mas apenas da ação e da busca, adquirimos, graças ao curso natura dos afetos, um interesse pelo próprio fim, e sentimos um desconforto se nossa busca fracassa.

${ }^{8}$ Hume (2009, p. 328): “[...] as regras gerais têm grande influência sobre o orgulho e a humildade, bem como sobre todas as outras paixões. [...] O costume facilmente nos leva a ultrapassar os justos limites em nossas paixões, assim como em nossos raciocínios."

\section{André Vicente Pintor}

A aquisição de fins pelo sujeito representa, na teoria de Hume, um acordo entre o mundo das relações e a existência do dado: “É nesse sentido que a finalidade se reintroduz. Ela será pensada, não conhecida, como o acordo original dos princípios da natureza humana com a própria Natureza" (DELEUZE, 2001, p. 82). A subjetivação é, portanto, um acordo do sujeito com o dado, no qual aquele se subordina a este para a consecução de fins. Entra em jogo, assim, o princípio da utilidade: "O sujeito é essa instância que, sob o efeito de um princípio de utilidade, persegue um alvo, uma intenção, organiza meios em vista de um fim" (ibid., p. 110).

“Ao fazer do prazer um fim, os princípios da paixão dão à ação seu princípio, fazem da perspectiva do prazer um motivo de nossa ação" (ibid., p. 140) ${ }^{7}$. Na perseguição do prazer e no afastamento da dor, portanto, o sujeito encontra a orientação para a sua ação. E é na forma como persegue estes objetivos que está fundada a teoria moral de Hume.

Sendo o passional e o social as duas formas pelas quais o espírito é afetado, o sujeito encontra-se sempre dividido entre fazer o que ele próprio deseja e fazer o que a sociedade demanda dele. O que deseja o sujeito? E o que deseja a sociedade? Hume trabalha sob a perspectiva de que o indivíduo está sempre buscando realizar seus desejos. Assim, sua melhor opção é atingir imediatamente seus fins o que não quer dizer, entretanto, que sejam egoístas. "Uma das ideias mais simples de Hume, porém uma das mais importantes, é esta: o homem é muito menos egoísta do que parcial" (ibid., p. 32). Como o próprio Hume afirma: "só poucos homens deixam de destinar a maior parte de sua fortuna aos prazeres de sua esposa e à educação dos seus filhos, reservando tão-somente a menor parte para seu uso próprio e sua diversão pessoal" (HUME apud DELEUZE, 2001, p. 32). Mais adequada, para Deleuze, é a ideia de "simpatia".

A simpatia significa que o ser humano não é simplesmente auto-interessado, mas autocentrado. Ela trabalha com a ideia de que somos generosos, mas limitadamente. A simpatia é o estado natural das paixões humanas, que agem sempre sobre a base assentada pelos princípios da associação. Se os efeitos dos princípios da associação são a contiguidade, a semelhança e a causalidade, é por estes tipos de associação que a simpatia está naturalmente limitada. Todavia, esta limitação pode ser superada ${ }^{8}$ - e é aqui que se encontra o fundamento da moral.

Esta concepção altera radicalmente a concepção contratualista de sociedade, que acredita que seu propósito é o da limitação dos egoísmos para que os indivíduos possam conviver. Ao trabalhar com a ideia de simpatias limitadas, Hume atribui à estrutura social o papel de integração das simpatias, para que elas possam ultrapassar sua limitação natural:

[...] o problema da sociedade não é o de limitação, mas de integração. Integrar as simpatias é fazer com que a simpatia ultrapasse sua contradição, sua parcialidade natural. Tal integração implica um mundo moral positivo e se efetua na invenção positiva de um tal mundo. (DELEUZE, 2001, p.

[...] a essência da sociedade não é a lei, mas a instituição. A lei, com efeito, é uma limitação dos empreendimentos e das ações, e retém da 
${ }^{9}$ Em Hume (2009, p. 659): “A maior parte das invenções humanas estão sujeitas a mudanças. Dependem do humor e do capricho. Permanecem em voga durante um certo tempo, e então caem no esquecimento."

10 Em Hume (2009, p. 592): “o governo é uma mera invenção humana no interesse da sociedade; quando a tirania do governante contraria esse interesse, suprime a obrigação natural da obediência." sociedade um aspecto tão-somente negativo. [...] A instituição não é uma limitação, como é a lei, mas é, ao contrário, um modelo de ações, um verdadeiro empreendimento, um sistema inventado de meios positivos, uma invenção positiva de meios indiretos. (ibid., p. 42)

O mundo moral surge, portanto, de uma necessidade natural. Mas isto não quer dizer que ele esteja determinado pela natureza: "a necessidade é natural, mas a satisfação da necessidade ou, pelo menos, a constância e a duração dessa satisfação só podem ser artificiais, industriais e culturais" (ibid., p. 39). Ele é um artifício humano, criado para permitir "ao meu interesse particular, assim como ao de outrem, satisfazer-se e realizar-se" (ibid., p. 36); é uma produção humana que amplia as paixões para que a satisfação do interesse de outrem seja também meu interesse e, assim, garante meios para que todas as paixões se realizem. Sua característica não é limitar, mas possibilitar - razão pela qual Hume não trata as regras gerais como leis proibitivas, mas como modelos de ação compartilhados.

A sociedade é um conjunto de convenções fundadas na utilidade, não um conjunto de obrigações fundadas em um contrato. [...] A utilidade, vínculo entre instituição e necessidade, é, pois, um princípio fecundo: o que Hume chama de regra geral é uma instituição. (ibid., p. 43)

Aqui entendemos por que o "mundo moral" de Hume pode ser entendido sob o conceito de "cultura": as regras gerais que regem a vida em sociedade não partem de um além-mundo ou de um princípio abstrato de razão, mas dos hábitos compartilhados e prescritos de um povo. Por sua vez, não há nada que determine o conteúdo desses hábitos, senão o próprio costume: "É essa a diferença entre o instinto e a instituição: há instituição quando os meios pelos quais uma tendência se satisfaz não são determinados pela própria tendência, nem pelos caracteres específicos" (ibid., p. 44) ${ }^{9}$. O mundo moral de Hume, portanto, é histórico; os costumes são históricos; e a avaliação das ações humanas deve considerar sua tendência de promover o bem ou o mal segundo determinadas circunstâncias.

Por mais que Deleuze imprima este movimento a Hume, entretanto, há um porém a ser ressaltado: se em Hume os costumes devem ser entendidos segundo seu sequenciamento histórico, por um lado - o que decorreria em um relativismo cultural -; por outro, fica aberta a possibilidade de se planejar e avaliar esses costumes segundo sua utilidade, chegando-se a um ponto final na organização social onde todos os problemas estariam solucionados. É por isto que Deleuze comenta, por exemplo, que para Hume

Se os governantes, em vez de mudar sua situação, em vez de adquirir um interesse imediato na execução da justiça, submetem a execução de uma justiça falsificada às suas próprias paixões tornadas imediatas, então, e somente então, a resistência é legítima em nome de uma regra geral. (DELEUZE, 2001, p. 49)

A história passada é diferencial, mas a futura pode ser unificada por regras gerais cada vez mais abrangentes. É esta a ideia de civilização à qual a teoria de Hume ainda está muito fortemente ligada. Se este trabalho discorre sobre o movimento teórico de distanciamento dessa noção, a filosofia de Hume é apenas um instante inicial e ainda modesto desse distanciamento, tendo como 


\section{André Vicente Pintor}

principal contribuição a utilização da historicidade como critério de justificação dos costumes humanos.

Vejamos agora um momento mais avançado no afastamento da ideia de civilização, apresentado aqui por intermédio da obra de Norbert Elias em seu anos iniciais.

\section{A Cultura em Elias}

Se no Tratado da Natureza Humana a palavra "cultura" sequer chega a aparecer, n'O Processo Civilizador ela certamente aparece. Porém, Elias não se apropria explicitamente do termo como um instrumento teórico de sua investigação, mas apresenta-lhe como um conceito próprio ao povo alemão. Nesta seção, argumentaremos como podemos entender o conceito de cultura em Elias, que, embora não seja idêntico ao alemão, retira deste sua essência.

Não sendo idêntico ao conceito de Kultur possuído pelos alemães, o conceito que identificamos em Elias é a aplicação desse conceito à ideia (principalmente francesa) de "civilização". N'O Processo Civilizador, Elias reserva uma seção inteira para a explicação da sociogênese dos conceitos de "civilização" e de "cultura", seção esta que informará o esforço interpretativo que realizaremos a seguir:

“A palavra pela qual os alemães se interpretam, que mais do que qualquer outra expressa-lhes o orgulho em suas próprias realizações e no próprio ser, é Kultur" (ELIAS, 1994b, 1º vol., p. 24). Essas realizações, por sua vez, se dão no domínio do "das rein Geistige", isto é, o puramente espiritual; são as realizações "em livros, trabalhos de erudição, religião, arte, filosofia, no enriquecimento interno, na formação intelectual (Bildung) do indivíduo, principalmente através de livros, na personalidade"

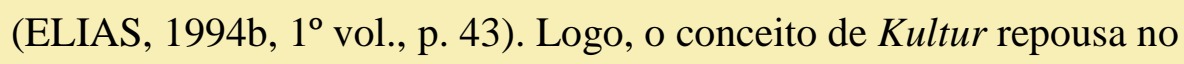
que são consideradas as realizações espirituais de um povo. Mas por que esse conceito tomou essa forma?

A história do conceito de Kultur está intimamente relacionada à história da intelligentsia alemã dos séculos XVII e XVIII. Entender o lugar social desta classe é entender as propriedades do conceito, formulado por ela.

Arrasada por guerras (como a famosa Guerra dos Trinta Anos), a terra que hoje conhecemos por Alemanha era, nesses séculos, muito pouco desenvolvida e integrada. Diferentes povos habitavam suas diferentes regiões, em diferentes Estados, estabelecendo apenas limitados contatos entre si. Seu comércio não tinha grande envergadura e a classe burguesa era, por isto, muito debilitada. Por outro lado, a nobreza, que também não tinha uma situação farta e na qual, "nos casos em que [havia] recursos suficientes, as pessoas [imitavam] insatisfatoriamente a conduta da corte de Luís XIV” (ibid., p. 29), embora débil - ou justamente por isto - compunha uma classe social altamente hermética, resistente à penetração de qualquer outro grupo social alemão. Até mesmo a língua que as duas classes usavam eram diferentes: enquanto a burguesia se utilizava cotidianamente do alemão, a nobreza considerava-a "uma língua semibárbara, que se fraciona em tantos dialetos diferentes como a Alemanha tem províncias" (FREDERICO, 


\section{André Vicente Pintor}

O GRANDE, apud ELIAS, 1994b, $1^{\circ}$ vol., p. 31), preferindo utilizarse do francês. Havia também uma separação quanto às funções de ambas as classes: diferentemente da sociedade francesa, na qual os burgueses ascendiam regularmente à corte e assumiam, assim, influências e cargos políticos, a política dos Estados alemães estava completamente restrita à nobreza.

Nesta sociedade extremamente estratificada, a burguesia alemã começa a desenvolver-se - longe de pressões populares, mas também distanciada da nobreza. Excluída da arena política, a única esfera que resta para sua projeção é a das artes. Todavia, como o país não era ainda integrado, não seria qualquer arte a desenvolver-se: aquelas que dependessem da reunião de pessoas nos mesmos lugares que as obras de arte, irreproduzíveis - condição que restringe a pintura e a escultura, por exemplo -, não teriam como sustentar-se. Assim, o espaço no qual a burguesia alemã lançou-se e acabou por dominar foi o da literatura: na segunda metade do século XVIII, o país passa por uma vertiginosa expansão literária que marcaria para sempre a história mundial. Esta expansão, por sua vez, dependeu de um importante fator: o consenso de uma pequena parcela da burguesia, a dos intelectuais, quanto ao que seria o bom alemão, pois, como já mencionamos, a Alemanha era ainda formada por diversos estados, e "cada grupo local [estava] convencido de que seu patois é o melhor" (FREDERICO, O GRANDE, apud ELIAS, 1994b, $1^{\circ}$ vol., p. 31).

A intelligentsia foi justamente essa classe de intelectuais que, pela publicação de inúmeras obras literárias, foram responsáveis por disseminar e consolidar não somente uma língua alemã comum, mas também os ideais de uma classe.

A situação desta classe tinha seu análogo em quase todos os maiores Estados alemães e em muitos dos menores. No topo, por quase toda a Alemanha, situavam-se indivíduos ou grupos que falavam francês e decidiam a política. No outro lado, havia uma intelligentsia de fala alemã que de modo geral nenhuma influência exercia sobre os fatos políticos. De suas fileiras saíram basicamente os homens por conta dos quais a Alemanha foi chamada de terra de poetas e pensadores. E deles, conceitos como Bildung e Kultur receberam seu cunho e substância especificamente alemães. (ELIAS, 1994b, $1^{\circ}$ vol... p. 33-34)

Foram os "servidores de príncipes" cultos que tentaram, em primeiro lugar, criar, em uma classe intelectual particular, os modelos do que o alemão é e, desta maneira, estabelecer pelo menos nesta esfera intelectual, uma unidade alemã que ainda não parece realizável na esfera política. $O$ conceito de Kultur tem a mesma função." (ibid., p. 30 , grifo nosso)

O conceito de Kultur surge então como síntese de uma forte oposição social, conglomerando os ideais burgueses em uma oposição à ideia de Zivilisation, que representava os costumes e crenças da nobreza alemã. Ele serviu como expressão da autoimagem burguesa em distanciamento à nobreza cortesã, e tudo o que era relacionado a esta era abominado pela primeira: a "cortesia externa enganadora" (ELIAS, 1994b, $1^{\circ}$ vol., p. 29), a imoralidade e a frigidez intelectual (ibid., p. 36), a importância da boa forma (ibid., p. 34), "a sede de distrações, de novos atavios, de admiração por um trajo, uma peça de mobiliário, um novo prato absurdo" (ROCHE 


\section{André Vicente Pintor}

apud ELIAS, 1994b, $1^{\circ}$ vol., p. 41). Todas estas características, vistas como fúteis pela intelligentsia alemã, foram contrapostas a uma autêntica virtude ética, ligada às realizações "espirituais", que comporia o núcleo dos costumes burgueses. Se a civilização, ligada à forma dos comportamentos, representava o orgulho francês e inglês (assimilado pela nobreza alemã) "pela importância de suas nações para o progresso do Ocidente e da humanidade" (ELIAS, 1994b, $1^{\circ}$ vol., p. 24); se se referia a "fatos políticos ou econômicos, religiosos ou técnicos, morais ou sociais" (ibid.); se ela é entendida não apenas como um estado, mas como um processo que deve avançar (ibid., p. 62); e se "até certo ponto, o conceito de civilização minimiza as diferenças nacionais entre os povos", enfatizando o que há (ou deveria haver) de comum entre eles (ibid., p. 25), então o conceito de Kultur nada pode ter dessas características.

A Kultur não seria política ou econômica, mas intelectual estaria intimamente relacionada com a Bildung (a nutrição do intelecto) e seus produtos; não estaria patente na forma dos comportamentos, mas seria uma característica abstrata que se manifestaria no conteúdo de suas produções. Mais importante, Kultur não expressa em si uma "tendência continuamente expansiva" de nações que muito cedo consolidaram sua identidade e se expandiram para fora de suas fronteiras (ELIAS, 1994b, $1^{\circ}$ vol., p. 25): diferentemente de civilisation, sua orientação e ênfase é para a demarcação e as diferenças entre grupos; volta-se para as produções intelectuais porque está interessada no local da expressão da individualidade de uma classe. "O conceito de Kultur delimita" (ibid., p. 24).

N'O Processo Civilizador, Elias delimita dois momentos do conceito de Kultur: o primeiro é o do surgimento do conceito e de sua utilização como um ferramenta de posicionamento social e conflito entre classes. Com a ascensão da burguesia às esferas políticas e ao controle nacional, entretanto, o conceito é expandido a nível nacional, deixando de ser representante somente da consciência de uma classe e passando a representar todo o povo alemão.

Com a lenta ascensão da burguesia alemã, de classe de segunda categoria para depositária da consciência nacional e, finalmente - muito tarde e com reservas - para classe governante, de uma classe que, no início, foi obrigada a se ver ou legitimar principalmente se contrastando com a classe superior aristocrática de corte e, em seguida, definindo-se contra nações concorrentes, a antítese entre Kultur e Zivilisation, com todos seus significados correlatos, muda em significação e função: de antítese primariamente social torna-se primariamente nacional." (ibid., p. 47, grifo do autor)

Acreditamos ser este o momento no qual se encontra a obra de Elias. É claro que, em 1939, ano da publicação d'O Processo Civilizador, a burguesia já estava estabelecida como classe governante, e a Alemanha já tinha alguma ideia de seu lugar no sistema internacional. Porém, como o próprio autor menciona, a Alemanha fora "uma nação que teve de buscar e constituir incessante e novamente suas fronteiras, tanto no sentido político como espiritual e repetidas vezes perguntar a si mesma: 'Qual é, realmente, nossa identidade?"” (ibid., p. 25). Esta era uma realidade que não estava 


\section{André Vicente Pintor}

ainda desfeita à sua época, principalmente levando-se em consideração a atuação e protagonismo de seu país nas duas Grandes Guerras.

Como alemão que olha para o sistema internacional no qual precisa se inserir, Elias se debruça sobre a crença na civilização dominante na sociedade internacional e originária dos dois grandes inimigos alemães na Primeira Guerra Mundial: Inglaterra e França -, procurando na história o traçado de suas origens; trata-a como produto espiritual de um povo e busca, em registros documentais, seu caráter único, fenômeno da individualidade desse povo. Esta individualidade é, então, encontrada na transição da sociedade medievo-feudal para a dos Estados absolutistas, em um processo de autocontrole corporal e psíquico que Elias denominou "processo civilizador”. É nesta análise que buscaremos as concepções eliasianas sobre a cultura, pois é na investigação histórica do sentido de "civilização" que acreditamos que se localiza a diferença entre a concepção eliasiana e a alemã.

A investigação de Elias remonta ao que ele identifica como núcleo da noção de civilização: a noção de "civilidade" (civilité), que adquire seu sentido moderno com Erasmo de Rotterdam, na obra De Civilitate Morum Puerilium (Da Civilidade em Crianças), publicada em 1530 (ELIAS, 1994b, $1^{\text {o }}$ vol., p. 68). Nesta obra, dedicada a um menino nobre, Erasmo trata de como deve ser o comportamento das pessoas em sociedade, principalmente aquele que se refere ao "decoro corporal externo" (ibid., p. 69). Por todo o tratado, o autor aborda como devem ser a postura, os gestos, o vestuário, as expressões faciais, etc. Isto porque acredita que "este comportamento 'externo' [...] é a manifestação do homem interior, inteiro" (ibid., p. 69). Este tratado de Erasmo teve grande repercussão, mesmo em sua época, o que indica que seu objeto era uma preocupação corrente daquela sociedade.

São diversos os exemplos literários apresentados por Elias que atestam uma certa obsessão com o controle corporal, datando de períodos tão antigos quanto o século XII. Desde esta época, a tradição oral era repleta de poemas mnemônicos que visavam educar jovens e adultos à mesa, na realização de suas funções corporais e no relacionamento entre os sexos. Esta tradição foi registrada em livros como O Convidado Italiano, o Book of Nurture, Hofzucht e Tischzuchten (ibid., p. 74-75), que mostram que a preocupação com os bons modos era muito anterior a Erasmo. A essa época, tais comportamentos eram ainda tratados como particulares a uma classe, a cortesã, e utilizados primariamente para a distinção social; surge o conceito de cortesia, expressão da autoimagem dessa classe superior.

O padrão de 'bom comportamento' na Idade Média, como todos os padrões depois estabelecidos, é representado por um conceito bem claro. Através dele, a classe alta secular da Idade Média, ou pelo menos alguns de seus principais grupos, deu expressão à sua autoimagem, ao que, em sua própria estimativa, tornava-a excepcional. $\mathrm{O}$ conceito que resumia a autoconsciência aristocrática e o comportamento socialmente aceitável apareceu em francês como courtoisie [...] (ibid., p. 76)

No decorrer do século XVI, entretanto, o uso do conceito de courtoisie diminui lentamente, dando lugar ao uso mais difundido do 


\section{André Vicente Pintor}

conceito de civilité. Para Elias, "isto é sinal de uma mudança comportamental de grandes proporções” (ibid., p. 83), na qual as pessoas passaram a encarar as coisas "com mais diferenciação, isto é, com um controle mais forte de suas emoções" (ELIAS, 1994b, $1^{\circ}$ vol., p. 84). Não só isto, mas a obra de Erasmo é também o marco de uma difusão dessas regras para outros estratos sociais:

Erasmo não vê seus preceitos como dirigidos a uma classe particular. Não atribui ênfase especial

a distinções sociais, se ignoramos a crítica ocasional a camponeses e pequenos negociantes.

É precisamente essa falta de orientação social específica nos preceitos, sua apresentação como regras humanas gerais, que lhe distingue o tratado dos que o sucederam na tradição italiana e, especialmente, francesa. (ibid., p. 88)

Tem início a época que Elias denomina "humanista", na qual o conceito de civilidade expande a obrigação de uma conduta controlada, originária da nobreza cortesã e de sua realidade específica, para os demais estratos sociais: primeiro aos "homens de honra" e, posteriormente, a toda a sociedade. Os mecanismos desta expansão estão intimamente ligados ao que divisamos como a noção eliasiana de cultura.

A expansão do alcance dos bons modos e da etiqueta operada pelo conceito de civilité levou a uma dinâmica na qual "as pessoas se moldavam às outras mais deliberadamente do que na Idade Média" (ibid., p. 91). Se antes eram abundantes, na tradição oral, os versos sobre bom comportamento, sua sistematização em tratados literários por pensadores da envergadura de Erasmo é um claro sinal da crescente importância do tema. Com a ampliação das situações sociais nas quais se requeria a etiqueta, também "aumenta a coação exercida por uma pessoa sobre a outra e a exigência de 'bom comportamento' é colocada mais enfaticamente" (ibid.).

Não é na coação externa do comportamento que está a principal dinâmica que Elias observa no processo civilizador, porém; mas na intensificação do controle social a um ponto em que se tornasse interno, automatizado, inconsciente. A este movimento, o autor relaciona a monopolização da força física e a estabilidade de órgãos administrativos que levam à consolidação do Estado moderno.

De uma sociedade feudal povoada por inúmeros núcleos humanos autônomos, a sociedade ocidental passa por uma lenta transição para um governo e uma economia centralizados, que partiam, inicialmente, de um príncipe e, posteriormente, de uma "coletividade". Isto foi possível devido a disputas territoriais nas quais os senhores feudais mais poderosos conquistaram seus adversários e centralizaram em si seu poder, acumulado em suas terras e aliados. Com esta centralização, os príncipes tomaram para si o direito à guerra, pacificando internamente a região que dominavam e obrigando os antigos cavaleiros a viverem em sua órbita. Foi assim que se formaram as cortes cavaleirosas - e, posteriormente, somente cortes, pois seus integrantes já tinham perdido seu caráter cavaleiroso. Por sua vez, é nas cortes e em seu monopólio das funções políticas que se consolida a estabilidade das funções administrativas daquilo que veio se tornar o Estado no sentido como o entendemos hoje.

É preciso haver uma divisão social muito avançada de funções antes que possa surgir uma 
máquina duradoura, especializada, para administração do monopólio. E só depois que surge esse complexo aparelho é que o controle sobre o exército e a tributação assumem seu pleno caráter monopolista. (ELIAS, 1994b, $2^{\circ}$ vol., p. 98)

É da diferenciação social do que antes eram cavaleiros - os senhores responsáveis pela administração dos diversos âmbitos de uma unidade político-territorial autônoma - em cortesãos - membros da nobreza que orbitam o poder central, localizado no príncipe, e auxiliam-no nas funções administrativas de seu território -, portanto, que reside a fundamentação dos monopólios que consolidam o Estado moderno. Por sua vez, é "graças à centralização e à monopolização [que] oportunidades que antes tinham que ser conquistadas por indivíduos com emprego de força militar ou econômica tornam-se passíveis de planejamento" (ibid., p. 105). Inicialmente, este planejamento está completamente voltado à figura do príncipe e visa conquistar seus favores. Com o avanço da diferenciação social, entretanto, "a teia humana, com sua elevada e crescente divisão de funções, é impelida por seu próprio peso coletivo para um estado de equilíbrio em que se torna impossível a distribuição das vantagens e renda das oportunidades monopolizadas em favor de uns poucos" (ibid., p. 103). Quando se atinge este ponto, os monopólios privados das classes superiores passam a se tornar, gradualmente, públicos, ou estatais. Isto faz com que "as oportunidades proporcionadas pelo monopólio [passem] a ser distribuídas cada vez menos segundo o favor pessoal e no interesse de indivíduos, e cada vez mais de conformidade com um plano mais impessoal e exato" (ibid., p. 105).
Tanto a dinâmica cortesã de buscar as graças dos príncipes como a capacidade de planejamento que surge com a estabilidade das instituições políticas são fundamentais para entendermos como o controle do comportamento, característico da civilité, passa a ser internalizado.

Como vimos, é no enfraquecimento dos cavaleiros independentes e em sua busca de favores nas ricas Casas dos grandes príncipes que consiste a sociogênese da sociedade de corte. Estas cortes se diferenciam fortemente do resto da sociedade, sendo local de alto prestígio. Não é à toa, portanto, que os preceitos do bom comportamento e do decoro corporal tenham se disseminado tão vigorosamente na sociedade de corte: eram marca desse prestígio, dessa distinção social;

Para seu próprio convívio, [o rei] precisava de uma sociedade cujas maneiras fossem as suas. $\mathrm{O}$ fato de que as pessoas que o serviam à mesa, quando ia dormir ou quando caçava, pertencessem à mais alta nobreza da terra servia à sua necessidade de distinguir-se de todos os outros grupos do país. (ELIAS, 1994b, $2^{\circ}$ vol., p. 224)

Por outro lado, as cortes, cada vez mais, se tornaram local de confluência de elementos sociais - não só cavaleiros de diferentes Casas, como se deu no início, mas também dos mais altos estratos burgueses, como posteriormente se deu - e, logo, local de intensos conflitos e tensões permanentes. Diferentemente do que acontecia na era feudal, entretanto, essas tensões não podiam se resolver pela violência, pois estavam todos sob o favor do príncipe: "a espada fora substituída pela intriga e por conflitos nos quais as carreiras e o sucesso social eram perseguidos por meio de palavras" (ibid., p. 225). 


\section{André Vicente Pintor}

Com o constante monitoramento dos hábitos corporais e com as disputas cortesãs sendo travadas pela intriga e pelas palavras, uma nova classe de habilidades passa a ser requisitada. "A reflexão contínua, a capacidade de previsão, o cálculo, o autocontrole, a regulação precisa e organizada das próprias emoções, o conhecimento do terreno, humano e não-humano, onde agia o indivíduo, tornaramse precondições cada vez mais indispensáveis para o sucesso social" (ibid., p. 226). Estas habilidades, por sua vez, levam a uma crescente e compulsória consciência de si: os elementos da corte se veem obrigados a se enxergarem como indivíduos e a medirem as consequências de suas ações.

\section{O controle mais complexo e estável da conduta passou a ser cada vez mais instilado no indivíduo desde seus primeiros anos, como uma espécie de automatismo, uma autocompulsão à qual ele não poderia resistir, mesmo que desejasse. A teia de ações tornou-se tão complexa e extensa, o esforço necessário para comportar-se 'corretamente' dentro dela ficou tão grande que, além do autocontrole consciente do indivíduo, um cego aparelho automático de autocontrole foi firmemente estabelecido. (ibid., p. 196)}

A autocompulsão por controle cria uma complexidade no indivíduo que não existia antes. Ele passa a ver não apenas mais facetas de si mesmo, como também dos demais. "A imagem que ele forma dos outros torna-se mais rica em nuanças, mais isenta de emoções espontâneas, - ela é, numa palavra, 'psicologizada"' (ibid., p. 227). Seu aparato psíquico se divide e ele passa a observar suas próprias ações a partir do ponto de vista de um "superego".

Esse autocontrole é instilado tão profundamente desde essa tenra idade que, como se fosse uma estação de retransmissão de padrões sociais, desenvolve-se nele uma autosupervisão automática de paixões, um 'superego' mais diferenciado e estável, e uma parte dos impulsos emocionais e inclinações afetivas sai por completo do alcance direto do nível de consciência." (ibid., p. 202)

É por ação deste superego, então, que o indivíduo passa a se controlar automaticamente. É ele a internalização do controle social dentro do corpo do próprio indivíduo, sua psique. É o superego, portanto, o produto fundamental do processo civilizador; são suas capacidades de controle e de autoavaliação que permitem a observação calma e planejada da realidade. A racionalidade, principal mote da sociedade civilizada, só é possibilitada por meio do superego. É ele a característica peculiar da sociedade que cunhou e expandiu a civilização; é ele seu Geist, sua cultura.

Vemos como Elias entende a ideia de "civilização" muito diferentemente dos franceses. Para o autor, ela não é uma conquista que determinado povo ou classe de pessoas possui, uma espécie de legado histórico adquirido por mérito científico ou racional. Ela é, sim, um conjunto de comportamentos que se estabeleceram segundo um percurso histórico específico que se deu devido às formas de interação dos indivíduos em sociedade. Ela é vista como algo próprio de um povo, que o delimita e diferencia dos demais. Não poderia, portanto, ser um caminho natural de uma espécie de desenvolvimento humano: ela é um modo particular de se localizar no mundo; uma autoimagem. Esta percepção é formada por uma historicização precisa e muito bem-informada, tanto do termo "civilização", quanto dos comportamentos a ele relacionados. 


\section{André Vicente Pintor}

Esta ampla historicização de costumes sociais realizada por Elias desperta nossa atenção para a ideia de cultura e nos faz questionar: como o autor entende a dinâmica dos costumes sociais? Qual é a sua concepção profunda sobre como esses costumes são iniciados e movimentados? A quem estes costumes devem ser atribuídos (aos indivíduos, a grupos, a uma sociedade como um todo, a nenhum destes)? O que eles nos informam sobre a condição humana? Nenhuma destas questões é profundamente tratada n'O Processo Civilizador, mas o são n'A Sociedade dos Indivíduos. Neste tratado, escrito no mesmo ano d'O Processo Civilizador, Elias apresenta sua perspectiva ontológica sobre o que vem a ser a esfera social humana, explicando como podemos entendê-la e a seus mecanismos de reprodução. É nele que buscamos aporte para indicarmos a concepção de cultura que desponta a partir do autor, ainda que ele não se utilize deste termo para falar de sua própria produção.

O tratado se inicia com uma crítica à famosa oposição presente na sociologia entre indivíduo e sociedade. Seu argumento principal é o de que um não pode ser entendido sem o outro, pois ambos se constituem mutuamente.

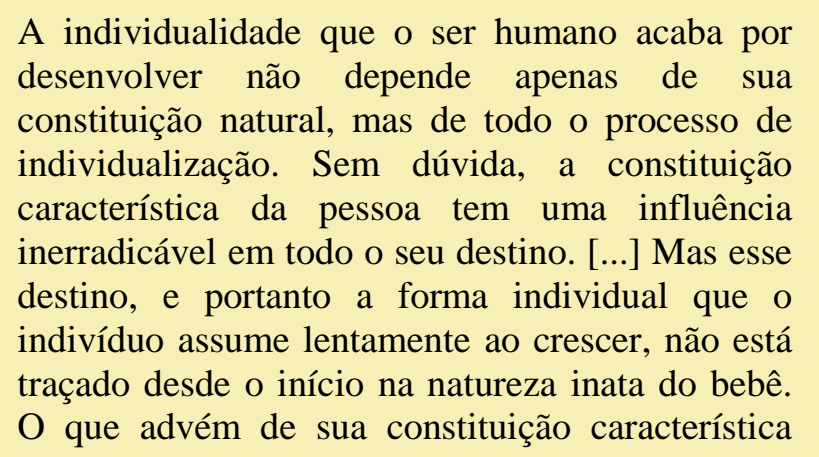

depende da estrutura da sociedade em que ele cresce. (ELIAS, 1994a, p. 28)

[...] cada pessoa singular está realmente presa; está presa por viver em permanente dependência funcional de outras; ela é um elo nas cadeias que ligam outras pessoas, assim como todas as demais, direta ou indiretamente, são elos nas cadeias que a prendem. [...] É a essa rede de funções que as pessoas desempenham umas em relação a outras, a ela e nada mais, que chamamos "sociedade". (ELIAS, 1994a, p. 23)

O pressuposto básico de Elias, portanto, presente em toda a sua teoria, é o de que a relação que existe entre indivíduos e sociedade não é a de premência de um sobre o outro, mas de dualidade - os próprios termos de "indivíduo" e "sociedade" são problematizados pelo autor, preferindo ele tratar de processos de sociogênese e psicogênese. A consequência disto é que, metodologicamente, nenhum fenômeno social pode ser entendido como unidirecional: os processos que partem da vida em coletividade (do que chamamos, aqui, de cultura) ocorrem simultaneamente nas duas direções, de formação de fenômenos psíquicos e sociais. Isto se deve à natureza básica do ser humano, que nos leva a viver em sociedade: nossa interdependência.

Todo indivíduo nasce num grupo de pessoas que já existiam antes dele. E não é só: todo indivíduo constitui-se de tal maneira, por natureza, que precisa de outras pessoas que existam antes dele para poder crescer. Uma das condições fundamentais da existência humana é a presença simultânea de diversas pessoas inter-relacionadas. (ibid., p. 27) 


\section{André Vicente Pintor}

A interdependência é, assim, a estrutura básica da sociedade. É ela o caráter comum a todo e qualquer grupo humano, independentemente da forma que tomem seus costumes e crenças. Pela interdependência, as pessoas entram em interações que têm sua forma determinada pela estrutura social; por sua vez, como não podem nunca estar isentas de entrar em relações, essas mesmas pessoas mudam a estrutura social a cada nova interação que estabelecem.

Por outro lado, não são apenas as formas de interação que têm importância fundamental, mas também os sentidos atribuídos a elas. Às interdependências que compõem a estrutura social acrescenta-se também a esfera do sentido, fundamental para como as pessoas constituirão "as imagens variáveis de seus objetivos".

[...] tanto os indivíduos quanto a sociedade conjuntamente formada por eles são igualmente desprovidos de objetivo. Nenhum dos dois existe indivíduos em sociedade é o material, o tecido básico em que as pessoas entremeiam as imagens variáveis de seus objetivos. (ibid., p. 18)

O Processo Civilizador é um atestado de todas essas considerações teóricas que Elias apresenta em A Sociedade dos Indivíduos. Analisando a história da ideia de civilização, o autor percebe um contínuo processo de influência mútua entre relações interdependentes que compõem as estruturas sociais e os sentidos que surgem delas e nelas retroagem - esta é a trajetória que se traça no processo pelo qual a ideia de cortesia se transforma em civilidade e, posteriormente, em civilização, em um movimento que expande a abrangência do conceito de relações entre os membros da corte para membros da sociedade e, posteriormente, até mesmo para outros países.

A noção de cultura que divisamos em Elias é o que fundamenta essa observação por parte do autor: ela é entendida como um modo próprio segundo o qual um grupo humano organiza suas relações de interdependência e adquire sentido de si. Não só isto, mas ela também são os produtos deste modo que retroagem sobre ele e o atualizam perpetuamente. Da mesma forma com que indivíduo e sociedade formam uma dualidade, a cultura que toma forma em Elias não pode ser entendida simplesmente como um produto humano nem como condição de existência. Deve ser, necessária e simultaneamente, ambos.

O caráter histórico da existência humana em Elias se mostra justamente nesse contínuo processo de produção de realidades mentais e corporais individuais e coletivas: para que o superego, isto é, o controle das emoções pudesse se estabelecer como a característica distintiva da civilização, centenas de anos foram necessários para que comportamentos corporais fossem se internalizando como saberes. Neste longo processo, o próprio conhecimento desta dinâmica se perde em meio aos anos necessários para realizá-lo, o que nos distancia também da concepção humiana: outros processos adquirem preponderância na manutenção dos hábitos, para além da ação refletida. Não há regras gerais a serem verificadas no interesse de todos; há apenas regras de etiqueta, normas de conduta, gabaritos de controle e autocontrole. A seguir, 


\section{André Vicente Pintor}

${ }^{11}$ Em seu sentido transcendental, ao menos.

12 Traduzida para o português pela editora Imago no $19^{\circ}$ volume de sua coleção das obras completas de Freud. determinação da cultura.

\section{Os Processos da Cultura}

explicitaremos alguns desses processos que entram em jogo na

A noção de cultura que subjaz à obra de Elias está relacionada, principalmente, a uma independência da cultura com relação às ações individuais. Por mais que processos coletivos e individuais se interpenetrem e, portanto, a cultura dependa da realização de ambos, nem um nem outro podem planejar como retroagirão na cultura: "embora todas essas sociedades certamente tenham consistido e consistam em nada além de muitos indivíduos, é claro que a mudança de uma forma de vida em comum para outra não foi planejada por nenhum desses indivíduos" (ELIAS, 1994a, p. 12). Ainda mais do que na proposta de Hume - principalmente em sua vertente política -, a razão perde lugar: se em Hume ela não é uma razão transcendental, mas prática, no sentido de ser a prática refletida que se corrige individual e coletivamente, em Elias ela chega ao limite de se tornar meramente uma prática comportamental de um grupo como qualquer outra. Mais importantes são os processos mentais e corporais de conformação social. A seguir, explicaremos alguns dos conceitos que informam Elias em sua análise e lhe permitem desconsiderar a razão ${ }^{11}$ como um princípio da organização social, rompendo com a teoria social de pretensões civilizatórias.

Aparato Psíquico e Superego
A ideia de que nossa mente é composta segundo uma divisão especial de sistemas psíquicos ganha a forma que tem atualmente (e que tinha à época de Elias) com os trabalhos da psicanálise, cujo maior representante é Freud. Neste autor, podemos observar uma série especial de artigos nos quais a estrutura e o funcionamento da mente são imaginados segundo diversos critérios de classificação. $\mathrm{Na}$ introdução a $O$ Ego e o $I d^{12}$, o editor inglês James Strachey nos informa sobre essa série de artigos, que se encadeiam cronologicamente na seguinte ordem: o "Projeto", o Capítulo VII de A Interpretação dos Sonhos, os artigos metapsicológicos e o próprio O Ego e o Id (STRACHEY, 1996, p. 16). Destes, estará apresentado aqui somente o conceito de aparato psíquico que se desenha no último e mais aperfeiçoado deles, $O E g o$ e $o I d$, e que influenciou e influencia até hoje os escritos psicanalíticos; os artigos sobre a metapsicologia serão utilizados para dar o panorama do desenvolvimento da teoria de Freud até a concreção de sua noção de aparato psíquico em $O$ Ego e o Id.

Em todos os artigos que trataram da divisão da mente, "os problemas inter-relacionados do funcionamento mental e da estrutura mental foram inevitavelmente considerados" (ibid.). Nos primeiros escritos, a hipótese da repressão que adveio dos estudos da histeria levou Freud a dividir a mente em duas regiões: uma reprimida, igualada ao que era inconsciente, e outra repressora, consciente. Pouco a pouco, o Inconsciente tomou forma não apenas de um local que abrangia processos mentais com determinadas características (inconscientes), mas também de um sistema que, sendo uma parte 
${ }^{13}$ Segundo Freud (1974b, p. 140), a necessidade causada pelo instinto é um incômodo ao sistema nervoso, que se vê ativado. O postulado básico assumido aqui é aquele da fisiologia no qual "o sistema nervoso é um aparelho que tem por função livrar-se dos estímulos que lhe chegam, ou reduzi-los ao nível mais baixo possível", buscando uma condição impossível na qual estaria inteiramente livre de estímulos.

\section{André Vicente Pintor}

específica da estrutura mental, tinha seus próprios métodos de processar os pensamentos, diferentes dos modos conscientes. Por algum tempo, o "ego" foi identificado com a parte consciente que se opunha ao Inconsciente, mas, quando Freud percebe que "o próprio ego deveria ser parcialmente descrito como "inconsciente", (ibid., p. 17), a distinção entre sistemas conscientes e inconscientes perde utilidade e é abandonada. A categorização que o autor estabelece em $O$ Ego e o Id é resultado desta nova percepção, na qual a consciência ou inconsciência de um processo mental não mais deve estar identificada a um local mental particular, mas ao modo pelo qual ele é processado.

Vemos que, fundamentais para a compreensão do aparato psíquico proposto por Freud, são as ideias de repressão e de consciência. Por sua vez, fundamental a estas ideias e a toda a psicanálise é a proposição de que somos afetados por estímulos nervosos que recebem o nome de "instintos". Para consolidarmos uma ideia sobre o aparato psíquico, portanto, é primordial que revisitemos essas ideias.

Para Freud, "o elemento ao mesmo tempo mais importante e mais obscuro da pesquisa psicológica" são os instintos (FREUD apud STRACHEY, 1974, p. 131). Estes, por sua vez, podem ser entendidos como um tipo particular de estímulo ao sistema nervoso, que têm sua origem dentro do próprio corpo humano: não apenas internos, os instintos têm também a característica peculiar de serem contínuos: "um instinto [...] jamais atua como uma força que imprime um impacto momentâneo, mas sempre como um impacto constante"
(FREUD, 1974b, p. 138, grifo do autor). "Por [esses motivos], ele atua diferentemente sobre a mente, e diferentes ações se tornam necessárias para removê-lo" (ibid.).

Enquanto estímulos externos são passíveis de evasão pelo corpo e pelo sistema nervoso - pelo afastamento da fonte de estímulo -, o mesmo não acontece com os instintos: um instinto nunca pode ser eliminado; não há fuga dele. A única alternativa possível ao incômodo causado pela necessidade ${ }^{13}$ a que leva um instinto é a sua satisfação temporária. Todavia, não é sempre que um instinto pode ser satisfeito, o que leva nosso corpo a recorrer a outras estratégias: a mente encarrega-se de dar outros rumos ao instinto que não sua satisfação direta.

"Um instinto nunca pode tornar-se objeto da consciência - só a ideia que o representa pode. Além disto, mesmo no inconsciente, um instinto não pode ser representado de outra forma a não ser por uma ideia" (FREUD, 1974a, p.203). Mesmo quando Freud fala de um impulso instintual inconsciente, o que ele quer dizer é que o representante mental deste impulso é inconsciente, pois o instinto, por si só, sequer chega à mente (STRACHEY, 1974, p. 130). A ideia de um representante mental do instinto resume o conceito de "pulsão". E é somente através das pulsões que a mente pode dar outro rumo aos instintos e à sua satisfação. Segundo Freud (1974b, p. 147), são quatro os caminhos que uma pulsão pode percorrer ao ser processada pela mente: reversão a seu oposto, retorno em direção ao próprio self do indivíduo (identificação), repressão ou sublimação. Apenas a repressão e a identificação representam interesses para nosso 
${ }^{14}$ Sem dúvida que o Id é, ele todo, inconsciente. Todavia,

inconsciência é uma característica que agora se estende para conteúdos de todos os sistemas mentais. (FREUD, 1996, p. 37)

\section{André Vicente Pintor}

trabalho, pois é da primeira que Elias tira as principais características do que entende por "superego" - termo do qual se utiliza constantemente para explicar o autocontrole que o processo civilizador instila no indivíduo e dele requisita -, mas é da segunda que Freud propõe a ideia de superego. Ademais, a noção de aparato psíquico não fica inacessível ao abandonarmos os outros dois caminhos possíveis às pulsões.

"Uma das vicissitudes que um impulso instintual pode sofrer, é encontrar resistências que procuram torna-lo inoperante. Em certas condições, [...] o impulso passa então para o estado de "repressão", (FREUD, 1974c, p. 169). Essas condições são, basicamente, a de que o desprazer que virá como sanção à satisfação do instinto seja maior do que o prazer que advirá de sua satisfação, e que, por isto, a mente entenda que é mais vantajoso "se esquecer" da pulsão que representa o instinto: "a essência da repressão consiste simplesmente em afastar determinada coisa da consciência, mantendo-a à distância" (ibid., p. 170, grifo do autor), o que ela faz mediante uma retirada da catexia de energia (ibid., p. 178). Com a pulsão afastada da consciência, ela fica livre para se organizar, dar origem a derivados e estabelecer ligações (ibid., 172). Pela ação deste mecanismo, que Freud chama de "formação de substitutos", o instinto tem a energia retirada da pulsão que o representa e dirigida a outros objetos mentais, o que abre caminho para sua satisfação indireta.

Na concepção atualizada d'O Ego e o $I d$, o responsável por todo o processo de repressão e substituição que mencionamos acima é o ego. Diferentemente de escritos anteriores, porém, o fato de este processo de repressão ser consciente ou inconsciente é indiferente: o ego, agora, é representado como a instância repressora que impede que algumas pulsões e pensamentos se tornem conscientes, independentemente de os processos pelos quais realiza esta função serem conscientes ou inconscientes eles próprios. Por outro lado, a origem dos instintos cujas pulsões constantemente interpelam o ego estão no que agora não mais é tratado como o "Inconsciente", mas como " $I d " 14$.

O Id é visto como o substrato biológico da existência humana; ele é aquilo que é transmitido e herdado geracionalmente: sua origem e substância é filogenética. É dele, portanto, que partem os instintos. O ego, por sua vez, é a interação desse domínio do código genético com o que Freud chama de "realidade", que é o mundo externo aos limites corporais e que neles imprime sua influência; ele é "aquela parte do $I d$ que foi modificada pela influência direta do mundo externo" (FREUD, 1996, p. 39). O ego surge a partir do sistema perceptivo, que processa os estímulos externos, e se utiliza desses estímulos para guiar o corpo em sua existência no ambiente; sua responsabilidade é a de servir como "princípio da realidade", contrastando a busca incessante do Id por prazer com as possibilidades que a realidade apresenta a essa busca: "o ego representa o que pode ser chamado de razão e senso comum, em contraste com o id, que contém as paixões" (FREUD, 1996, p. 39).

Vimos que, representando o princípio da realidade, o ego é a instância que se esforça continuamente para conter os desejos irrefreáveis dos instintos do $I d$, que se apresentam a ele como 


\section{André Vicente Pintor}

pulsões. Uma das formas de o ego conter os instintos, como já vimos, é a repressão. A outra, que veremos agora, é a internalização do objeto de desejo.

"Quando acontece de uma pessoa ter de abandonar um objeto sexual, muito amiúde se segue uma alteração de seu ego que só pode ser descrita como instalação do objeto dentro do ego" (ibid., p 43). O objeto instalado dentro do ego é uma espécie de "negociação" deste com o $I d$, transformando-se ele próprio no objeto que, por causa de interdições, é negado àquele último. O superego, também chamado de "ideal do ego", é a série dessas internalizações operadas pelo ego, com vistas a controlar o $I d$, que direcionam as catexias deste para o que seria um ego ideal, almejado. Como tal, ele representa, para o ego, um modelo de comportamentos e crenças a serem observados, auxiliando-o no controle do $I d$. Por outro lado, submete também o ego aos desejos do $I d$.

Um caráter marcante do superego na obra de Freud é que ele é uma aquisição cultural:

Se considerarmos mais uma vez a origem do superego, tal como a descrevemos, reconheceremos que ele é o resultado de dois fatores altamente importantes, um de natureza biológica e outro de natureza histórica, a saber: a duração prolongada, no homem, do desamparo e da dependência de sua infância, e o fato de seu complexo de Édipo [...]. De acordo com uma hipótese psicanalítica, o fenômeno por último mencionado, que parece ser peculiar ao homem, constitui uma herança do desenvolvimento cultural tornado necessário pela época glacial. (ibid., p. 47-48)
Como cultural, o superego depende da experiência de cada ser individual com relação aos outros de seu grupos - mais especificamente, às interdições que estes lhe impõem, tendo em vista que o fundamento cultural se localiza no complexo de Édipo. Como representação dos interesses do Id no ego, entretanto, ele está profundamente vinculado aos instintos e à biologia humana: "através da formação do ideal, o que a biologia e as vicissitudes da espécie humana criaram no id e neste deixaram atrás de si, é assumido pelo ego e reexperimentado em relação a si próprio como indivíduo" (FREUD, 1996, p. 49). O que não fica claro é como o ideal do ego, dependendo da interação do Id com a experiência, possa possuir "os vínculos mais abundantes com a aquisição filogenética de cada indivíduo" (FREUD, 1996, p. 49), isto é, como a experiência de cada indivíduo possa se transformar em uma herança genética.

Freud remedia o problema acima descrito pela hipótese de que

As experiências do ego parecem, a princípio, estarem perdidas para a herança; mas, quando se repetem com bastante frequência e com intensidade suficiente em muitos indivíduos, em gerações sucessivas, transformam-se, por assim dizer, em experiência do id, cujas impressões são preservadas por heranças. Dessa maneira, no id, que é capaz de ser herdado, acham-se abrigados resíduos das existências de incontáveis egos; e quando o ego forma seu superego a partir do id, pode talvez estar apenas revivendo formas de antigos egos e ressuscitando-as. (FREUD, 1996, p. 51)

É aqui que a abordagem do autor nos interessa, pois é neste ponto que influencia fortemente as concepções de Elias. Por mais que este autor trabalhe mais com a capacidade repressiva - que na 


\section{André Vicente Pintor}

verdade é do ego - e trate do superego sem tratar da internalização objetal que ele opera, o que é importante de se observar aqui é a capacidade que contínuos desvios nos caminhos das pulsões têm de operar uma mudança no próprio Id. Em Elias, isto se mostrará na capacidade que os arranjos históricos que se desenrolam ao longo do tempo têm de mudar a própria "estrutura mental e emocional" (ELIAS, 1994b, $1^{\circ}$ vol., p.70) das pessoas, criando disposições novas que estão muito mais relacionadas à cultura do que a uma natureza genética - de onde sua defesa de que as disposições de interdependência psicossocial só podem ser entendidas segundo sua história.

\section{Interdependência}

Localizamos em Georg Simmel o desenvolvimento primeiro da ideia de interdependência que influenciará Elias. Aqui, apresentaremos brevemente o conceito a partir das concepções filosóficas que levaram o autor até ele, utilizando-nos da obra As Aventuras de Georg Simmel como um guia ao "labirinto" de fios emaranhados "que ele vai tecendo à medida em que se movimenta" (WAIZBORT, 2000, p. 101).

As investidas de Simmel pelos mais diversos temas sociológicos podem ser reunidas sob o procedimento que ao próprio autor ocorreu chamar de "cultura filosófica". Tal procedimento se refere a uma atitude frente ao mundo e aos objetos de conhecimento; uma atitude na qual se busca, incessantemente, olhá-los sob novas perspectivas, novas relações.
Em Simmel, o mundo se constitui pelo dualismo entre sujeitos e objetos, que se opõem continuamente. Entretanto, nem sujeito nem objeto podem ser entendidos como algo fixo, definido: em suas incontáveis tensões, um constrói ao outro e se deixa por ele construir, em uma contínua e infinita atualização de si próprios.

Simmel concebe a relação do homem com a natureza, enquanto uma relação de sujeito e objeto, como uma relação conflituosa, e essa relação está posta inclusive no interior do próprio espírito. O espírito produz as mais diversas formações, que passam a ter uma autonomia própria; o sujeito, com isso, passa a confrontar-se com essas formações. Nestas, o espírito convertese em objeto. (WAIZBORT, 2000, p. 116)

O mundo de Simmel, portanto, divide-se "entre a vida subjetiva, o que é incessante mas temporalmente finito, e seus conteúdos, que, uma vez criados, são imóveis, mas válidos intemporalmente" (SIMMEL apud WAIZBORT, 2000, p. 116). E, na oposição entre esses dois polos (o da vida e o da forma), situa-se a cultura.

Como ponto de toque entre o sujeito e os objetos, a cultura é o local em que o espírito se objetiva e os objetos espirituais são reabsorvidos no processo de cultivo (Bildung) da personalidade, no “desenvolvimento de nossa totalidade interior" (ibid., p. 121). Ela é a "síntese única do espírito subjetivo e do espírito objetivo" (ibid., p. 123) e, como tal, ela é um local de movimento incessante.

É justamente na busca pelo movimento incessante que consiste a proposta de "cultura filosófica" simmeliana: para o autor, o essencial à filosofia “não é, ou não é apenas, o conteúdo, que é a cada 
vez conhecido, construído, pensado, mas sim uma determinada atitude espiritual em relação ao mundo e à vida" (ibid., p. 16) atitude esta que consiste justamente em se apropriar mentalmente dos objetos do espírito das formas mais variadas possíveis, tecendo deles percursos que partam nos mais diversos sentidos e a eles retornem de outras tantas inumeráveis origens. Fica aqui uma dúvida: como estas relações estabelecidas entre os objetos poderão fazer sentido, se não se visa tecer as linhas de um sistema? Como o emaranhado pode deixar de ser simplesmente um emaranhado quando a cada tentativa, a cada ensaio sociológico, o autor não está preocupado em fixar os fios que teceu?

Simmel não precisa se preocupar em reatar os fios que tece, formando assim um todo, pois o todo está presente em cada fio, cada ensaio, cada movimento construtivo e de objetivação. Aliás, o autor nem poderia tentar criar um todo, pois as relações deste são tão numerosas que escapam a qualquer tentativa de delimitação.

No que é mais indiferente, que em seu fenômeno isolado nos é banal ou repugnante, nós só precisamos mergulhar profunda e afetuosamente $o$ suficiente para sentir também isto como brilho e expressão da unidade última de todas as coisas, da qual brota sua beleza e sentido e para qual toda filosofia, todo momento de nossas elevações mais altas de sentimentos, toda religião lutam por símbolos. (ibid., p. 75)

Esta é a sua ideia de um "panteísmo estético": um mundo no qual cada ponto abriga a realidade do todo, pois o absoluto e universal deságua em tudo aquilo que é particular e efêmero.

$\mathrm{O}$ ser divino penetra nas configurações particulares, e encontra nelas a sua vida criativa completa, o singular não se funde em deus e com isso perde sua forma palpável e significativa para si, senão que deus se dissolve no singular e este é, com isso, mantido e intensificado em sua forma particular; o caráter empírico-causal da coisa singular ganha como que uma legitimação transcendente. (SIMMEL apud WAIZBORT, 2000, p. 78)

Se cada ponto abriga o todo, entretanto, ele só o faz relativamente: como em uma obra de arte, a importância de cada elemento só se desvenda quando o todo de suas relações se substancia na pintura. Em Simmel, portanto, a análise de cada elemento é a análise de suas relações, pois somente assim ele se constitui num todo, ele próprio, e leva a um todo maior que ele.

De relação em relação, o mundo de Simmel torna-se um mundo de relações. Tudo está em relação com tudo. [...] Como tudo está em relação com tudo, a partir de qualquer ponto há vias virtuais de acesso a tudo [...], a totalidade não é nunca acabada, fixa e definitiva, ela apenas reluz por um instante em meio a um nexo feliz de relações que o sujeito elabora e põe a descoberto. (WAIZBORT, 2000, p. 87, grifo do autor)

Se Waizbort compara Simmel a um compulsivo fiandeiro, então os infindáveis fios que ele tece são as infindáveis relações que se estabelecem entre os elementos da realidade e que, somente enquanto são consideradas, podem nos levar a relances do todo que elas constituem. Estas relações não são tomadas apenas no sentido filosófico: quando Simmel se aproxima de seus objetos sociológicos, também os entende emaranhados em uma rede de relações mútuas (Wechselwirkung) (ibid., p. 99) que os constitui ao mesmo tempo em que constituem seu todo. É daqui que se delineia a ideia de 


\section{André Vicente Pintor}

interdependência que será posteriormente lapidada pela consideração da diferenciação funcional dos indivíduos em sociedade.

Quando Simmel transporta seu panteísmo estético para a análise sociológica da individualidade, ele entende que somente por sua relação com todos os outros elementos da sociedade é que um indivíduo se constitui enquanto tal. Em sua relação com os outros elementos, “o indivíduo procura a si mesmo". Ele procura se diferenciar na própria individualidade" (ibid., p. 493) e, ao ser um elemento no todo social, torna-se um todo em si mesmo (ibid., p. 500). Aqui fica clara a ideia de individuação e o porquê da busca contínua pelo cultivo da personalidade. Entretanto, a interdependência se mostra mais como uma necessidade identitária do espírito do que como um fenômeno de caráter sociológico.

A questão se torna propriamente sociológica quando o autor propõe, em Como as Formas Sociais se Mantêm, o caráter especificamente social que deve ser estudado pela sociologia: "a Sociologia deve buscar seus problemas não na matéria da vida social, mas em sua forma; inclusive é essa forma que dá o caráter social de todos aqueles fatos de que se ocupam as ciências particulares" (SIMMEL, 1983a, p. 47). Neste contexto, Simmel não está mais preocupado apenas com as relações dos indivíduos entre si, mas com como elas levam a formas estruturadas de interação. Aqui, organizados segundo diferentes funções, competindo e colaborando pelos mesmos fins, os indivíduos entram em "ações recíprocas permutadas" (ibid., p. 49), passando a exercer influência recíproca uns sobre os outros e sobre suas ações. É somente a partir deste momento que o autor entende que existe uma sociedade (SIMMEL, 1983b, p. 61). E é somente aqui que a interdependência ganha um significado sociológico como um arranjo específico no qual as ações de cada homem influenciam as de todos os outros na busca da consecução dos fins que almejam.

A interdependência demonstrada por Simmel para aí, como uma influência sobre ações no planejamento racional, decorrente da divisão social de funções pelos homens. Essencial para o entendimento de Elias, entretanto, é como essa interdependência se relaciona com os modos de agir e pensar socialmente compartilhados. Passaremos agora, portanto, pela contribuição que Karl Mannheim adiciona ao conceito.

Mannheim foi um notório sociólogo do conhecimento e, como tal, tinha como objetivo "o estudo dos processos mentais e suas significações em seu contexto social" (MANNHEIM, 1974, p. 66, grifo nosso). O contexto social é fundamental para a sociologia do conhecimento, pois ela toma como fundamento que os conhecimentos só podem surgir, continuar e descontinuarem-se, regredirem, progredirem e se renovarem de acordo com as condições de existência daqueles que o produzem. Estas condições, por sua vez, encontram-se todas na "matriz social" (ibid., p. 63) que os homens produzem em suas interações: "os homens cogitam enquanto membros de grupos e não como seres solitários" (ibid., p. 62) e, mesmo em momentos solitários, concebemos significados somente segundo nos foi transmitido por nossa socialização; "mesmo num 


\section{André Vicente Pintor}

estado isolado de contemplação executamos atos de sociabilidade" (ibid., p. 46).

A questão da socialização e da sociabilidade é fundamental para o conhecimento em Mannheim. Isto porque os significados que informam e compõem o conhecimento só passam a existir coletivamente: "são as ações coletivas, em situações dadas ou potenciais, que fixam a noção comum ou variável de uma coisa" (ibid., p. 47). Não só isto, mas a organização dos significados depende também das funções desempenhadas nas inter-relações que formam o todo social: "o caráter referencial da percepção depende de sua função e de seu habitat social" (ibid., p. 34). Aqui, portanto, a interdependência que marca a condição social moderna não se refere apenas à dependência material dos indivíduos uns para com os outros na perseguição de seus fins, mas é uma interdependência simbólica; ela marca a condição fundamental para a vida em sociedade; sinaliza a dependência do indivíduo para com suas relações em questões tão fundamentais quanto a aquisição de significados. Ademais, marca como esta aquisição é um processo contínuo e relacional que depende, a cada relação, não apenas da existência de outros elementos sociais, mas também da posição assumida referente a eles, pois "não há dúvida de que a personalidade só pode ser compreendida como um processo contínuo de integração" (MANNHEIM, 1974, p. 30, grifo nosso).

É esta concepção de interdependência que será fundamental em Norbert Elias e no conceito de cultura que observamos a partir dele. Neste autor, esta interdependência simbólica e relacional estará no centro dos processos de sociogênese e psicogênese, sendo, portanto, um de seus temas fundamentais.

\section{Saberes Incorporados}

A ideia de que existem saberes assimilados e desempenhados pelo corpo de forma inconsciente foi introduzida na ciência moderna através da corrente da psicologia que se convencionou chamar behaviorismo ou, sem anglicismos, comportamentalismo. $\mathrm{O}$ eventomarco desta corrente - quase seu mito fundador, recontado nas mais diversas disciplinas universitárias de psicologia -, foi o notório experimento de Ivan Pavlov, um fisiólogo russo, com a salivação em cães. A certa altura do experimento, Pavlov percebeu que seus cães salivavam ao avistarem o homem responsável por trazer-lhes sua comida, mesmo que este não a estivesse carregando no momento. $\mathrm{O}$ fato não passou sem atenção, tendo em vista que a saliva é uma resposta fisiológica que deveria ser esperada nos cães somente na presença de comida.

Ao estudar o caso mais a fundo, Pavlov chegou à conclusão de que os cães haviam associado a imagem de seu tratador com a comida que ele lhes dava, passando assim a salivar para ele como salivavam para a comida. Novamente, isto levantou dúvidas, tendo em vista que os cães não contam, como nós, com um aparato cognitivo-simbólico que lhes permita associar o tratador à comida como se ele fosse uma representação dela. A hipótese decorrente - e posteriormente confirmada - é que, pela associação repetida do tratador com a comida, aquele se tornou um estímulo substituto para 
${ }^{15}$ Sua importância como ponte entre as duas teorias é ainda mais ressaltada quando vemos que Watson é a única referência direta de Elias, n'O Processo Civilizador, a autores do behaviorismo.

16 Watson considera que a mente, pressuposto básico da psicologia introspectiva e seu fundamento enquanto disciplina, não passa de uma reformulação do problema uma reformulação do problema
religioso do corpo vs. alma. Nesta corrente, a mente seria $\mathrm{o}$ polo espiritual e, portanto, mais elevado desta dicotomia, o que o autor considera como não-científico.

\section{André Vicente Pintor}

a última, passando assim a ser entendido pelo corpo dos cães como equivalente. A descoberta revolucionou a psicologia, desqualificando a mente como único objeto possível de estudos psicológicos. A partir de então, surge a corrente behaviorista, preocupada em entender o comportamento humano por caminhos que não precisassem passar pela obscuridade da "mente" ou da "consciência" com que trabalharam os outros psicólogos até então.

Embora a contribuição de Pavlov tenha sido fundamental para o desenvolvimento do behaviorismo, não é dele que nos ocuparemos aqui, mas sim de outro dos grandes nomes desta corrente: John Watson. Este autor, em especial, recebe nosso interesse por ter sido citado diretamente por Elias no primeiro volume d'O Processo Civilizador, representando para nós, por isto, a ligação de Elias com o behaviorismo $^{15}$. A citação se refere especificamente à contribuição de Watson com a criação de termos como "socialização da criança", “formação de hábitos" e "condicionamento" (ELIAS, 1994b, $1^{\circ}$ vol., p. 260), e é utilizada para explicar o lugar dos poemas de tradição oral e escrita no "condicionamento" e "modelação" das crianças e adultos ao padrão de bons modos (ibid., p. 95). Desta forma, nos interessa aqui compreender como Watson entende esse processo pelo qual o corpo pode aprender comportamentos sem que a mente precise adquirir consciência sobre eles.

Em Behaviorism, Watson trata da corrente de psicologia que representa como uma investida científica de pesquisadores que estavam cansados de não chegar a nenhuma descoberta conclusiva utilizando-se dos pressupostos religiosos $^{16}$ da psicologia introspectiva, enquanto seus colegas da medicina, química e física viviam um momento prolífico em suas áreas (WATSON, 1930, p. 05). O que os psicólogos behavioristas fizeram, portanto, foi trazer os pressupostos e métodos das ciências naturais para a psicologia, restringindo-se a trabalhar estritamente com aquilo que pode ser observado (ibid., p. 06).

Circunscritos por aquilo que é observável nos seres humanos, os psicólogos behavioristas se limitaram a estudar nosso comportamento, entendido como "aquilo que o organismo faz ou diz" (ibid., tradução nossa). A classificação é bem ampla, mas carrega em si um elemento suficientemente restringente para diferenciar-se de trabalhos anteriores: os estudos estão restritos ao comportamento do organismo. Este, por sua vez, é entendido num sentido biológico: células geneticamente programadas se agrupam e formam tecidos, que compõem a estrutura corporal; estes tecidos são, principalmente, musculares, nervosos e glandulares (ibid., pp. 57-64; 77). Se, por um lado, os estudos estão restritos ao organismo, por outro, eles não podem desconsiderar nenhum de seus elementos constituintes. Portanto, "o aprendiz de comportamento humano [...] trabalha com a totalidade do corpo em ação" (WATSON, 1930, p. 48, tradução nossa).

Não podendo nos delongar muito sobre o método behaviorista, nos contentamos, aqui, com uma breve explicação que introduza seus principais conceitos:

Assim como Pavlov observou que o tratador se tornou, para os cães, um estímulo substituto para a comida, os principais trabalhos do 


\section{André Vicente Pintor}

${ }^{17} \mathrm{O}$ behaviorismo acredita que todas as habilidades corporais que aprendemos são aprendidas através de condicionamentos: a repetição da prática nos faz associar que nossas ações sempre levam a um mesmo estado no ambiente, o que nos leva a repetir aquelas ações com vistas ao fim que queremos. Se aprendemos a dirigir um carro, por exemplo, entendemos que toda vez que pisamos no pedal da direita o motor responde e que, quando a marcha está engatada e pisamos no mesmo pedal, o carro anda. A repetição uniforme desta situação é entendida como a aquisição de habilidade por parte da pessoa que passa a engatar a marcha e pisar no acelerador na expectativa de que o carro ande. behaviorismo consistem em investigar como o organismo humano e animal reage a diferentes estímulos sensoriais e como, com o condicionamento do corpo pela repetição, alguns estímulos se emparelham, desencadeando a mesma resposta do organismo.

O behaviorismo, portanto, trabalha com reações corporais a estímulos do ambiente e, segundo Watson, estas reações são sempre do corpo como um todo: no ser humano, a reação se dá por um funcionamento conjunto da organização manual, verbal e visceral (emocional) de seu corpo (ibid., p. 252). Ao aprendermos uma habilidade, por exemplo, através de condicionamento ${ }^{17}$, não apenas nossa organização motora passa a exibir respostas cada vez mais constantemente similares, mas também nossa disposição emocional frente à situação e nossa organização verbal dela se tornam padronizadas, o que indica que nosso corpo, como um todo, adquire aquela habilidade, independentemente de estarmos cientes das diversas esferas nas quais estamos reagindo àquela situação.

Esta descoberta do behaviorismo revolucionou a ciência moderna e é fundamental para nossa compreensão de saberes incorporados. Todavia, não é suficiente para tal pois, claramente, dá conta da questão de serem "incorporados", mas não pode dizer muito sobre o fato de serem "saberes". A própria questão da aquisição de "habilidades" se mostra uma dificuldade para os behavioristas quando consideramos o papel da linguagem neste processo: removida de seu caráter significante, perde-se a compreensão da capacidade da linguagem para a organização da experiência humana. Assim, as habilidades podem ser entendidas apenas como condicionamentos, mas não como saberes. Para superar esta limitação, utilizar-nos-emos de algumas considerações de Ernst Cassirer sobre o ser humano enquanto um animal simbólico.

O que diz Cassirer? Em primeiro lugar, o autor estabelece uma distinção marcante entre o homem e qualquer outro animal: somos capazes de fabricar símbolos, isto é, unidades de significado que abstraem "toda a variedade e heterogeneidade que nos é imposta pela natureza díspar de nossos sentidos” (CASSIRER, 1994, p. 79). Isto nos destaca do mundo da experiência imediata e nos transporta para uma "nova dimensão", um mundo abstrato, teórico, simbólico, no qual nossas respostas não são mais meras reações a estímulos externos, mas passam a ser sempre mediadas por significados (ibid., p. 47-48)

O homem não pode mais confrontar-se com a realidade imediatamente; não pode vê-la, por assim dizer, frente a frente. A realidade física parece recuar em proporção ao avanço da atividade simbólica do homem. Em vez de lidar com as próprias coisas o homem está, de certo modo, conversando constantemente consigo mesmo. Envolveu-se de tal modo em formas linguísticas, imagens artísticas, símbolos míticos ou religiosos que não consegue ver ou conhecer coisa alguma a não ser pela interposição desse meio artificial. (ibid., p. 48)

Quando falamos dos seres humanos, portanto, estamos sempre falando de uma interação mediada com o mundo, sendo muito raras as situações em que nosso corpo responde diretamente a estímulos externos. Sob este ponto de vista, a aquisição de uma habilidade nunca pode ser simplesmente mecânica, como exigem os 
18 Ver: MAUSS, Marcel. Uma Categoria do Espírito Humano: a noção de pessoa, a noção de "eu". In: Sociologia e Antropologia. São Paulo: Cosac Naify, 2003. P. 367-397.

\section{André Vicente Pintor}

pressupostos behavioristas, mas passam sempre por uma assimilação de significado; ainda que a habilidade possa alcançar uma mecanicidade tamanha que seja desempenhada inconscientemente, sua aquisição, no homem, nunca o é. Mesmo quando Cassirer fala do homem primitivo que navega no rio sem representá-lo em sua totalidade (CASSIRER, 1994, p. 79) - sem, por isto, ter um conhecimento teórico do rio -, ele não pode estar falando de um organismo que puramente reage ao ambiente: para o homem primitivo, o rio, suas margens, o arranjo das nuvens no céu enquanto navega e o próprio ato de navegar estão cheios de significado, ainda que ele não consiga expressá-los em termos abstratos.

Neste exemplo do homem primitivo que navega o curso do rio com familiaridade, mas sem representá-lo mentalmente é que está nossa chave para a compreensão dos saberes incorporados: ao desempenhar o ato da navegação, aquele homem certamente desempenha uma série de técnicas que lhe foram ensinadas desde sua infância, mas sobre as quais nunca lhe ocorreu a necessidade de refletir. Todos os significados sobre navegação que seu povo e sua tribo acumularam em suas formas linguísticas, imagens artísticas, símbolos míticos ou religiosos, e que lhes fizeram navegar da forma como navegam, culminaram em seu ato de uma forma inconsciente. De uma forma que poderia ser considerada meramente mecânica, ele manifesta e atualiza todo o universo simbólico do qual, por ser humano, ele não pode fugir.

\section{Conclusão}

Como pudemos ver ao longo das obras aqui analisadas, a empreitada de Elias em muito se assemelha à de Hume no tocante à capacidade histórica de condicionamento dos costumes humanos - é aqui que se encontra a principal continuidade entre as duas obras. Porém, as três ideias que acabamos de apresentar agregam-se inseparavelmente ao conceito de cultura que localizamos n' $O$ Processo Civilizador, atribuindo-lhe suas características peculiares e uma esfera própria de ação com referência à análise do ser humano e sua vida em sociedade. Os moldes nos quais a mente passa a ser entendida a partir dos adventos aqui apresentados são inovadores e bastante distintos, em suas consequências, da compreensão humiana:

Nossa compreensão de como a organização social age sobre os indivíduos se altera: o fenômeno psicológico individual se produz a partir da atualização, na experiência de cada pessoa, de relações culturais historicamente estruturadas; os processos da psicogênese dependem de um todo estruturado de comportamentos e significados inter-relacionados para poderem inculcar, em cada pessoa, esquemas funcionais que respondam ao seu ambiente social. Não é um conjunto de indivíduos que planejam e se refletem coletivamente que dão a tônica da esfera social, mas a interação entre pessoas ${ }^{18}$, elas próprias histórica e socialmente constituídas.

Seguindo na mesma linha, o caráter funcional-relacional do conhecimento impossibilita qualquer alusão a princípios universais de operação mental: mais do que sujeita à ação das demandas sociais, cada pessoa é constituída em sua integridade como um ponto no entrecruzamento das diversas relações que formam sua rede de 


\section{André Vicente Pintor}

sociabilidade. Uma pretensão de verificação da validade das estruturas sociais a partir de preceitos filosóficos como o da utilidade se vê cada vez mais impraticável, pois as próprias relações lógicas e os critérios de validação se mostram como compreensões historicamente estabelecidas e, muitas vezes, sequer refletidas.

A cultura, agora mais um modelamento necessário do que uma invenção útil, se desprende da necessidade de justificar-se. É este o rompimento com as pretensões civilizatórias que, iniciado em Hume, se concretiza em Elias.

\section{Referências}

BOAS, Franz. A Formação da Antropologia Americana: 1858-1942. Organização e introdução de George W. Stocking Jr. Tradução de Rosaura Maria C. L. Eichenberg. Revisão técnica de Marco Antônio T. Gonçalves e César Benjamin. Rio de Janeiro: Contraponto; UFRJ, 2004.

CASSIRER, Ernst (1944). Ensaio Sobre o Homem: introdução a uma filosofia da cultura humana. Tradução de Tomás Rosa Bueno. São Paulo: Martins Fontes, 1994. 391p. (Tópicos).

DELEUZE, Gilles. (1953). Empirismo e Subjetividade: ensaio sobre a natureza humana segundo Hume. Trad. de Luiz B. L. Orlandi. São Paulo: Editora 34, 2001. 160p. (TRANS)
ELIAS, Norbert (1939). A Sociedade dos Indivíduos. Organizado por Michael Schröter. Tradução de Vera Ribeiro. Revisão técnica e notas, Renato Janine Ribeiro. Rio de Janeiro: Jorge Zahar Ed., 1994a. 201p.

(1939). O Processo Civilizador. Tradução de Ruy Jungmann; revisão e apresentação de Renato Janine Ribeiro. Rio de Janeiro: Jorge Zahar Ed., 1994b. 2v.

FREUD, Sigmund. O Ego e o Id. In: Obras Psicológicas Completas de Sigmund Freud: edição standard brasileira. Comentários e Notas de James Strachey; em colaboração com Anna Freud; assistidos por Alix Strachey e Alan Tyson; traduzido do alemão e do inglês sob a direção geral de Jayme Salomão. Rio de Janeiro: Imago, 1996. pp. 25-80. 24v.

O Inconsciente. In: Obras Psicológicas Completas de Sigmund Freud: edição standard brasileira. Comentários e Notas de James Strachey; em colaboração com Anna Freud; assistidos por Alix Strachey e Alan Tyson; traduzido do alemão e do inglês sob a direção geral de Jayme Salomão. Rio de Janeiro: Imago, 1974a. pp. 191-245. $24 v$.

Os Instintos e suas Vicissitudes. In: Obras Psicológicas Completas de Sigmund Freud: edição standard brasileira. Comentários e Notas de James Strachey; em colaboração com Anna Freud; assistidos por Alix Strachey e Alan Tyson; 


\section{André Vicente Pintor}

traduzido do alemão e do inglês sob a direção geral de Jayme Salomão. Rio de Janeiro: Imago, 1974b. pp. 137-162. 24v.

Repressão. In: Obras Psicológicas Completas de

Sigmund Freud: edição standard brasileira. Comentários e Notas de James Strachey; em colaboração com Anna Freud; assistidos por Alix Strachey e Alan Tyson; traduzido do alemão e do inglês sob a direção geral de Jayme Salomão. Rio de Janeiro: Imago, 1974c. pp. 169-189. $24 \mathrm{v}$.

HUME, David. Tratado da Natureza Humana: uma tentativa de introduzir o método experimental de raciocínio nos assuntos morais. Tradução de Débora Danowski. 2. ed. São Paulo: UNESP, 2009.

MANNHEIM, Karl. Em Busca de uma Sociologia do Espírito. In: Sociologia da Cultura. Tradução de Roberto Gambini. São Paulo: Perspectiva; Ed. da Universidade de São Paulo, 1974. Pp. 0167. (Estudos).

SIMMEL, Georg. Como as Formas Sociais se Mantêm. In: MORAES FILHO, Evaristo de (org.). Georg Simmel: sociologia. Tradução de Carlos Alberto Pavanelli et al. São Paulo: Ática, 1983a. Pp. 46-58.

O Campo da Sociologia. In: MORAES FILHO, Evaristo de (org.). Georg Simmel: sociologia. Tradução de Carlos Alberto Pavanelli et al. São Paulo: Ática, 1983b. Pp.
O Problema da Sociologia. In: MORAES FILHO, Evaristo de (org.). Georg Simmel: sociologia. Tradução de Carlos Alberto Pavanelli et al. São Paulo: Ática, 1983. Pp. 59-78.

STRACHEY, James. Nota a Os Instintos e suas Vicissitudes. In: FREUD, Sigmund. Obras Psicológicas Completas de Sigmund Freud: edição standard brasileira. Comentários e Notas de James Strachey; em colaboração com Anna Freud; assistidos por Alix Strachey e Alan Tyson; traduzido do alemão e do inglês sob a direção geral de Jayme Salomão. Rio de Janeiro: Imago, 1974. pp. 129-135. 24v.

Nota a O Ego e o Id. In: FREUD, Sigmund. Obras Psicológicas Completas de Sigmund Freud: edição standard brasileira. Comentários e Notas de James Strachey; em colaboração com Anna Freud; assistidos por Alix Strachey e Alan Tyson; traduzido do alemão e do inglês sob a direção geral de Jayme Salomão. Rio de Janeiro: Imago, 1996. pp. 15-23. 24v.

WAIZBORT, Leopoldo. As Aventuras de Georg Simmel. São Paulo: USP, Curso de Pós-Graduação em Sociologia; Ed. 34, 2000. 592p.

WATSON, John B. Behaviorism. 2. ed. Chicago e Londres: Editora da Universidade de Chicago; Toronto: 1930. 308p. 